\title{
Enhancement of Soya bean (glycine max l.) Plants Growth, Yield and Seed Quality by using Putrescine, Benzyladenine and Yeast Extract
}

\author{
Reda M.Y. Zewail; Zakria M.A. Khedr; Faten H. M. Ismael and Elham F. Abd Elhameed \\ Botany Department Faculty of Agriculture Benha University \\ Corresponding author: reda.zewail@fagr.bu.edu.eg
}

\begin{abstract}
Two field experiments in randomized complete Block design (RCBD) were conducted at the experimental farm, Faculty of Agriculture Moshtohor, Benha university, Egypt during 2016 and 2017 seasons to study the effect of Putrescine at 5 and $10 \mathrm{mg} / \mathrm{L}$, Benzyl adenine (BA) at 20 and $40 \mathrm{mg} / \mathrm{L}$ and yeast extract at 50 and $100 \mathrm{ml} / \mathrm{L}$ on growth, photosynthetic pigments, phytohormones content, anatomical structures, flowering, characteristics; seed fuelling and yield of Soybeans (Glycine $\max$ L.) plants. Results showed that different applied treatments increased growth characteristics i.e., (plant height, leaf number, leaf area, branches number, fresh \& dry weights as well as the photosynthetic pigments and the endogenous phytohormones content. Also, stem and leaf anatomy measurements were increased especially (stem and leaf vascular and transporter tissues. In addition, flower setting was increased with putrescine, BA and yeast extract during 2016 and 2017 seasons. Also, yield and its characteristics were increased especially upper fully seeds, seed yield weight/plant during both seasons.
\end{abstract}

Key words: Soyabean, Putrscine, Benzyl adenine, Yeast extract, Growth, Phytohormones, anatomy.

\section{Introduction}

Soybean (Glycine max L.) is one from the most legumes widely grown crop and consumed oilseeds and the dairy alternative in the world. The large growth of soybean production can be attributed to various factors, with special mention of: High protein content (around 40\%) of excellent quality, both for human and animal feeding; high oil content of the seeds (around 20\%), which can be used for various purposes, especially for human feeding and biofuel production (Lazzarotto and Hirakuri, 2011). Through soyabean growth and development the plant loosing flower and new setting pods, by abortion and abscission may result in the reduction in number of pods and seeds (Nonokawaet al., 2012). Therefore, studies to increase soybean productivity have deserved much attention of researchers in recent years, Some researches show that, in normal conditions, the abscission of the reproductive structures of soybean can vary between 20 and $82 \%$ of the total number of flowers produced (Yashimaet al., 2005; Peterson et al., 2005). There aremany trials to decrease flower abscission and pod abortion through plant growth and developments. In this respect,benzyl adenine is an important plant hormone that regulates various processes of plant growth and development including cell division and differentiation, enhancement of leaf expansion and nutrient mobilization, improve crop quality and management Davies, (1995). Also, benzyl adenine (BA) belongs to a group of plant hormones called cytokinins and its role is connected with the growth and development of plants. It is also implicated in the vascular development and synthesis of secondary metabolites like indols, alkaloids and anthocyanins. It influences chloroplast differentiation and chlorophyll (Chl) biosynthesis Duszkaet al., (2009).In addition, Polyamines, mainly diamine putrescine (Put) are polycationic compounds of low molecular weight that are present in all living organisms reported by Liu $\boldsymbol{e t}$ al., (2007). It has been proposed as a new division of plant growth regulators that are reported to be involved in a large spectrum of physiological processes, such as embryogenesis, cell division, morphogenesis, and plant development (Bais and Ravishankar 2002; Liu et al., 2006a).Polyamines (Putrescine) play an important role in protecting plant against various a biotic stress, they are potent ROS scavengers and inhibitors of lipid peroxidation. The diamine Putrescine (Put) can alleviate harmful stress effects in plants by many ways including: polyamines (PAs) may be involved in free radical scavenging (Droletet al., 1986). It is modulators of stress regulated gene expression and exhibit antioxidant properties (Kuznetsov and Shevyakova, 2007 and Ahmed et al., 2012). Moreover, yeast extract is a natural component contains many of the nutrient elements and cytokinins, which is safe and nonpollutant. It has a considerable amounts of amino acids (Abou Zaid, 1984); mineral elements, carbohydrates, reducing sugars, enzymes and vitamins B1, 2, 3\&12 (Fathy and Farid, 1996 and Khedr and Farid, 2000). Also it is a source of cytokinins and protein that enhance cell division and enlargement (Barnett et al., 1990). Moreover, Yeo et al., (2000) found that yeast extracts contain trehalose6-phosphate synthase which is a key enzyme for trehalose bio synthesis. They suggested that production of trehalose not only effects on plant development but also improves drought tolerance. Many investigators reported that, spraying plants with yeast extract improved plant growth, yield and quality of many vegetable crops i.e. pea, tomato, potato, 
pepper and cucumber (Mohamed $\boldsymbol{e t}$ al., 1999; Yeo $\boldsymbol{e t}$ al., 2000; Abd-El-Hafez and Shehata, 2001 and Mahmoud, 2004). Moreover, El-Desuki and ElGereadly (2006) reported that, the vegetative growth of pea plant, leaves content of photosynthesis pigments, free amino acids, carbohydrates and cytokinins, pod yield and quality as well as nutritive value were increased by increasing the concentration of yeast extract in spraying solution from $1 \%$ up to $3 \%$.Therefore, the present study amid toinvestigate the effect of some growth substances i.e., putrescine, benzyl adenineand yeast extract on growth performance, abscission and flower setting, pod fuelling in the terminal part, yield and yield components of soyabean (Glycine maxL) plants.

\section{Material and Methods}

Two field experiments in randomized complete block design (RCBD) were conducted at the experimental farm, Faculty of Agriculture Moshtohor, Benha University, Egypt during 2016 and 2017 seasons to study the effect of Putrescine at 5 and 10 $\mathrm{mg} / \mathrm{L}$, Benzyl adenine (BA) at 20 and $40 \mathrm{mg} / \mathrm{L}$ and yeast extract at 50 and $100 \mathrm{ml} / \mathrm{L}$ on growth, flowering, flower setting and abscission, pod fuelling and yield of soybeans (Glycine max L.) plants. Different material putrescine and BA were brought from Algomhoria Company. Also, yeast extracts was prepared according to Abd EI-Rahim et al., (1988). The preparation of sowing land as recommended for soybean plants. All practical managements (fertilization, irrigation, pest control and etc....) were applied as recommended according to the Ministry of Agriculture. The seeds of soybean were sown on June $7^{\text {th }}$ and May $22^{\text {nd }}$ in 2016 and 2017 seasons, respectively. Soya bean seeds were drilled in rows, two seeds were sown and the distance between plant and other is $10 \mathrm{~cm}$. The soybean variety was Giza 111. Through plant growth and development the growth substances treatments were applied as foliar spray three times starts at $25^{\text {th }}$ days from sowing and after 20 days intervals for second and third one, respectively. The foliar spraying solution was added until the runoff from the plant.

\section{Sampling and Collecting Data:}

\section{I-Morphological Measurements:}

Different morphological Characteristics of soybean plants at 60 and 80 days after sowing were measured or estimated during 2016 and 2017 seasons. Nine plants from each treatment were randomly taken for the following measurements. Plant height, Stem diameter cm/plant., Number of leaves /plant, Number of branches/plant., Leaf area/plant. (by using disk methods according to Derieux and Montalanty., (1973). And fresh and dry weights of shoots.

\section{II- Photosynthetic Pigments:-}

Chlorophyll a, b and carotenoids were calorimetrically determined in the $4^{\text {th }}$ apical leaves of soybeans plant at 60 and 80 days after sowing according to the methods of Wettstein (1957) and calculated as $\mathrm{mg} / \mathrm{g}$ fresh weight.

\section{III- Phytohormones Determination:}

Endogenous phytohormones were quantitatively determined in soybean leaves at 60 days after sowing during 2017 season. According to the method of Koshioka et al., (1983) used for HPLC \{HighPerformance Liquid Chromatography\} for the determination of auxin (IAA), gibberellic acid $\left(\mathrm{GA}_{3}\right)$ and abscisic acid (ABA). Meanwhile, cytokinins were determined by HPLC according to Nicander et al., (1993).

\section{IV-Anatomical studies}

It was intended to carry out a comparative anatomical characteristics on stems and leaves of treated plants and those of the control at 60 days after sowing (flowering stage).Specimens of stems were taken from the 2 apical internode of the main stem while, those of the leaves were taken from the certain leaflet of the 2 apical leaf on the main stem. Anatomical studied were measured and calculated according to (Johanson, 1940).

\section{V- Flowering, Yield and yield component measurements:}

At flowering stage the flowers number, flower setting and abscission percentages, pods number/ plant were recorded and calculated. At harvest time, nine randomly plants from each plot were taken for estimation of the following parameters: plant height, number of branches, whole plant weight, number of pods/plant, number and weight of pods in the terminal part, number and weight of pods in the lower part, number of seeds in 10 pods, weight of seeds in pods, weight of 100 seeds, seed weight g/plant.

\section{VI-Statistical analysis:}

Data of morphological, flowering and yield characteristics were statistically analyzed and the means were compared using the Least Significant Difference test (L.S.D) at 5\% according to Snedecor and Cochran (1980).

\section{Results \& Discussions}

\section{I- Growth characteristics:-}

Growth characteristics of soya bean plants (Glycine $\operatorname{maxL}$ ) at 60 and 80 days after sowing as affected by different applied Putrscine at $5,10 \mathrm{mg} / \mathrm{L}$, Benzyl Adenine at 20 and $40 \mathrm{mg} / \mathrm{L}$ and yeast extract at $50 \& 100 \mathrm{ml} /$ Lare shown in Table (1).With regard to the plant height, stem diameter, leaves number /plant, number of branches and the total leaf area there were significantly increased with different applied treatments at 60 and 80 days after sowing during 2016 
and 2017 growing seasons. Also, it could be noticed that the highest increase of leaves number was obtained with Putrscine at $10 \mathrm{mg} / \mathrm{L}$ followed by Benzyl adenine at $40 \mathrm{mg} / \mathrm{L}$. Meanwhile, the lowest significant increase was existed with yeast extract at $100 \mathrm{ml} / \mathrm{L}$ at $60 \& 80$ days after sowing during both seasons. Here, the highest value of the number of branches existed with Benzyl Adenine at $40 \mathrm{mg} / \mathrm{L}$ at 60 and 80 days during 2016 and 2017 seasons. For the total leaf area the yeast extract at $100 \mathrm{ml} /$ Lgave the greatest and highest significantly increase at $60 \& 80$ days after sowing during 2016 and 2017 seasons. As for the shoots fresh and dry weights g/ plant were increased as the rest of characteristics. But the yeast extract at $50 \mathrm{ml} / \mathrm{L}$ gave the highest value of both weights when compared with the control at 60 and 80 days after sowing during 2016 and 2017 seasons.

In this respect, the obtained increase of growth parameters could be attributed to the beneficial effects of the applied growth substances i.e., Putrscine, Benzyl adenine and yeast extract on cell division, elongation and differenation. Also, yeast extract treatments are not only building blocks of proteins but also participate in many metabolic networks that control growth and adaptation to the environment Zewail et al., 2011 and Zewail (2014). Also, They are important in many biological molecules, such as forming parts of coenzymes, or as precursors for the biosynthesis of molecules such as glutamine and ornithine, which are precursors for nucleotides and polyamines, respectively (Alcázaret al, 2010) and also serve as major transport molecules of nitrogen from vegetative to reproductive tissues. Stimulate biosynthesis of endogenous cytokinins from roots. Enhancing leaf water status, some plant nutrients uptake, shoot growth and root pull strength (Demir et al. 2004) altering hormonal balances and favor cytokinins and auxins production (Schmidt 2005).

\section{II-Photosynthesis pigments content:}

Data in Table (2) indicate that different applied treatments were significantly increased chlorophyll A, b and carotenoids concentration at 60 and 80 days after sowing during first and second seasons. The highest treatment of chlorophyll a, b and cartnoides it was BA at 20 and $40 \mathrm{mg} / \mathrm{L}$ at 60 and 80 days after sowing during 2016 and 2017 seasons.In the context chl $\mathrm{a}+\mathrm{b}$ and chl $\mathrm{a}+\mathrm{b} /$ carotenoids ratio also, increased with different applied treatments in leaves of soyabean plants during first and second growing season (2016\&2017). In this respect, increased of chlorophyll contents could be attributed to that stimulation of putrscine, Benzyl adenine and yeast extract to protect photosynthetic apparatus of PSII (Zhang and Schmidt 2000). Also, protection of plant cells from lipid peroxidation and in activation of enzymes that occur under stress. Many biological molecules, such as forming parts of coenzymes, or as precursors for the biosynthesis of molecules such as glutamine and ornithine, which are precursors for nucleotides and polyamines, respectively.

\section{III-Endogenous phytohormones content:}

In Fig (5) data indicated that endogenous phytohormones content (i.e. Auxins, Gibberellins and Cytokinins were increased with Putrscine at $5 \& 10$ $\mathrm{mg} / \mathrm{L}$, Benzyl adenine at $20 \& 40 \mathrm{mg} / \mathrm{L}$ and yeast extract at 50 and $100 \mathrm{ml} / \mathrm{L}$ at 60 days of plant age during second growing season. Meanwhile, abscisic acid was decreased. In the context, the BA applications at $40 \mathrm{mg} / \mathrm{L}$ gave the highest concentration for auxins, cytokinins and gibberellins). Also, total promoters and total promoters /inhibitors ratio were increased when compared with control treatment.

In this respect, increasing of phytohormones content with different exogenous applied treatments it could be noticed that, Putrscine, BA, and yeast extract enhance biosynthesis of amino acids and different phytohormones during plant growth and development, thereby, increasing different growth charactractics, Table1), flowering and fruit setting, yield and yield components (Table 5) as well.The obtained results in case of yeast extract may be due to that yeast extract is considered as a natural source of cytokinins that stimulates cell division and enlargement as well as the synthesis of protein, nucleic acids and chlorophyll, also it contains sugar, proteins, amino acids and vitamins, especially B which may play an important role in improving growth and development (Fathy and Farid, 1996). In addition, exogenously applied of cytokinins increased endogenously cytokinins that stimulates cell division and enlargement as well as the synthesis of protein, nucleic acids and chlorophylls, also it contains sugar, proteins, amino acids. Thereby increased growth behavior Table (1), yield and yield components Table (5) and chlorophyll contents Table (2) could be expected.

\section{IV-Anatomical study:- \\ IV-A-Stem anatomy:-}

Data in Table (4) and Figs. ( 1 \&2) indicate the effect of different applied treatments(i.e., Putrescine $5 \& 10 \mathrm{mg} / \mathrm{L}$, benzyl adenine $20 \& 40 \mathrm{mg} / \mathrm{L}$ and yeast extract50\& 100ml $\backslash \mathrm{L}$ compared with the control( distilled water) on different anatomical features of Glycine max stem and leaf.

Data in Table (4) and Figs. (1\& 2) clearly indicate that all applied treatments increased the most stem anatomical features compared with the control. Obvious increase recorded in the thickness of many anatomical features especially with Putrescine at 10 $\mathrm{mg} / \mathrm{L}$.Here, number of vascular bundles, number of xylem rows in vascular bundle; number of xylem vessels in the row, the widest vessel thickness and thickness of xylem in large vascular bundle were reached their maximum values with Putrescine at 10 $\mathrm{mg} / \mathrm{L}$. While, the thickness of phloem were reached to $180,135,126,153,180$ and $171 \mathrm{M}$ with Putrescine at $5 \mathrm{mg} / \mathrm{L}$, Putrescine at $10 \mathrm{mg} / \mathrm{L}$, Benzyl adenine at 20 
$\mathrm{mg} / \mathrm{L}$, Benzyl adenine at $40 \mathrm{mg} / \mathrm{L}$, Yeast extract at 50 $\mathrm{ml} / \mathrm{L}$ and Yeast extract at $100 \mathrm{ml} / \mathrm{L}$, respectively, yet it was only $126 \mathrm{M}$ in control. Also, of interest it to note that the thickness of cambium region was reached to $80,90,85,79,81$ and $81 \mathrm{M}$ with Putrescine $5 \mathrm{mg} / \mathrm{L}$, putrescine $10 \mathrm{mg} / \mathrm{L}, \mathrm{BA}$ at $20 \mathrm{mg} / \mathrm{L}, \mathrm{BA}$ at $40 \mathrm{mg} / \mathrm{L}$, yeast extract at $50 \mathrm{ml} / \mathrm{L}$ and yeast extract at $100 \mathrm{ml} / \mathrm{L}$ , respectively, yet it was only $45 \mathrm{~m}$ in the stem of control. Generally, stem anatomical features increased with all treatments, Putrescine at $10 \mathrm{mg} / \mathrm{L}$ recorded the highest values in the important studied anatomical characteristics than the control or other treatments. Our results are in harmony with those reported by Nassar et al., (2011) on bean plants. Nofal et al., (2016) on marigold plant

\section{IV-b-Leaf anatomy:-}

Data in Table (5) and Figs. (3 \& 4) indicated that the effect of different applied treatments(i.e., Putrescine $5 \& 10$ at $\mathrm{mg} / \mathrm{L}$, benzyl adenine at $20 \& 40$ $\mathrm{mg} / \mathrm{L}$ and yeast extract at $50 \& 100 \mathrm{ml} / \mathrm{L}$ compared with the control( distilled water) on different anatomical features of Glycine max $L$. Leaflet. Thickness of midrib, thickness of blade, No of vascular bundles in midrib, length and width of large midrib vascular bundle, thickness of fiber in vascular bundle, thickness of phloem and xylem, number of xylem rows and vessel in vascular bundle and thickness of widest xylem vessel in vascular bundle. Numbers of vascular bundles were increased with some treatments compared with the control especially; benzyl adenine at $20 \mathrm{mg} / \mathrm{Land}$ yeast extract at 100mllL.As for the dimensions (its length and width) of the large vascular bundle of the midrib was increased with most treatments compared with the control especially, with putrescine at $10 \mathrm{mg} / \mathrm{L}$. Other treatments showed increase or decrease in one of these two characters. Also, of interest is to be note that the increase of transductory tissues i.e., xylem and phloem are of great importance since these tissues respent the passage of raw materials from roots to leaves through xylem tissue as well as the passage of different photsynthetase from leaves (source) to different plant parts ( sinks) through phloem tissue.

The obtained results are in harmony with those reported by Nassar et al., (2011) on bean plants. Nofal et al., (2016) on marigold plan
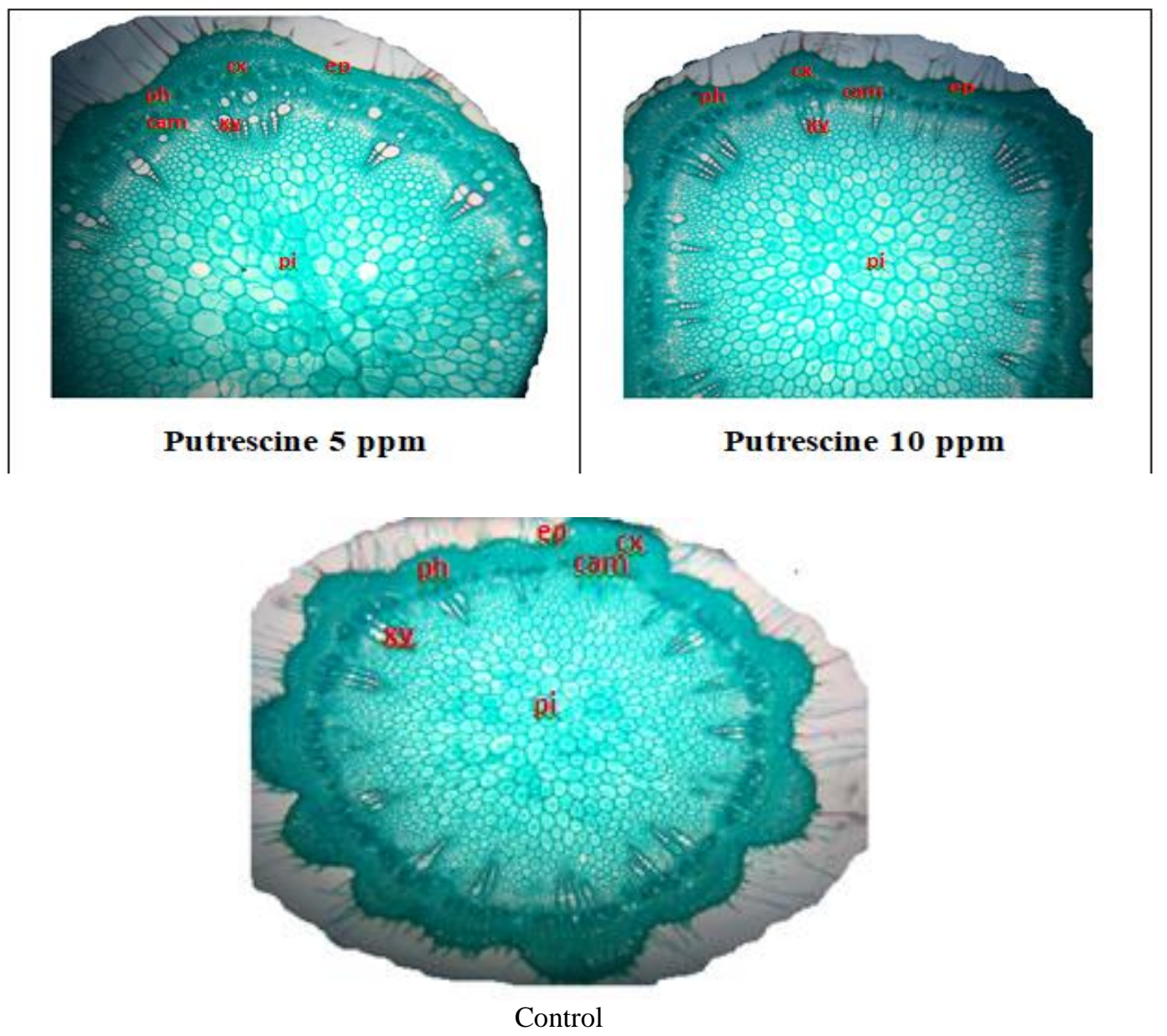

Fig. (1): Transverse sections $(X=24)$ through $2^{\text {nd }}$ internode of the main stem of soyabean plants at 60 days after sowing as affected by the different applied treatments.
$\mathbf{c x}=$ Cortex
ph $=$ Phloem tissue
cam=Cambium
$\mathrm{xy}=$ Xylem tissue
ep= Epidermis
pi= Pith 


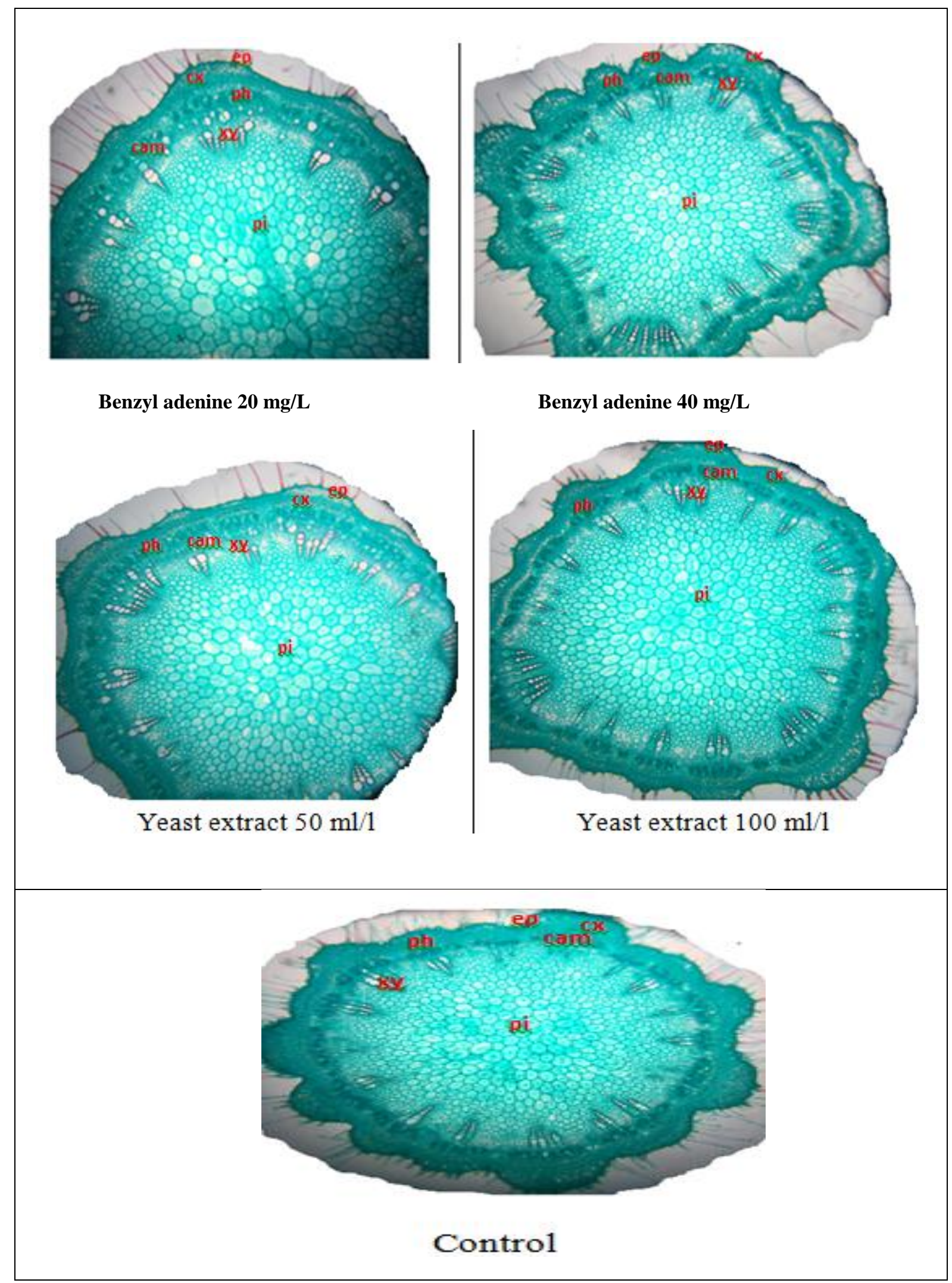

Fig. 2. Transverse sections $(X=24)$ through $2^{\text {nd }}$ internode of the main stem of soyabean plants at 60 days after sowing as affected by the different applied treatments.
$\mathrm{cx}=$ Cortex
$\mathrm{ph}=$ Phloem tissue
$\mathrm{ep}=$ Epidermis
cam=Cambium
$\mathrm{xy}=\quad$ Xylem tissue
pi $=$ Pith 


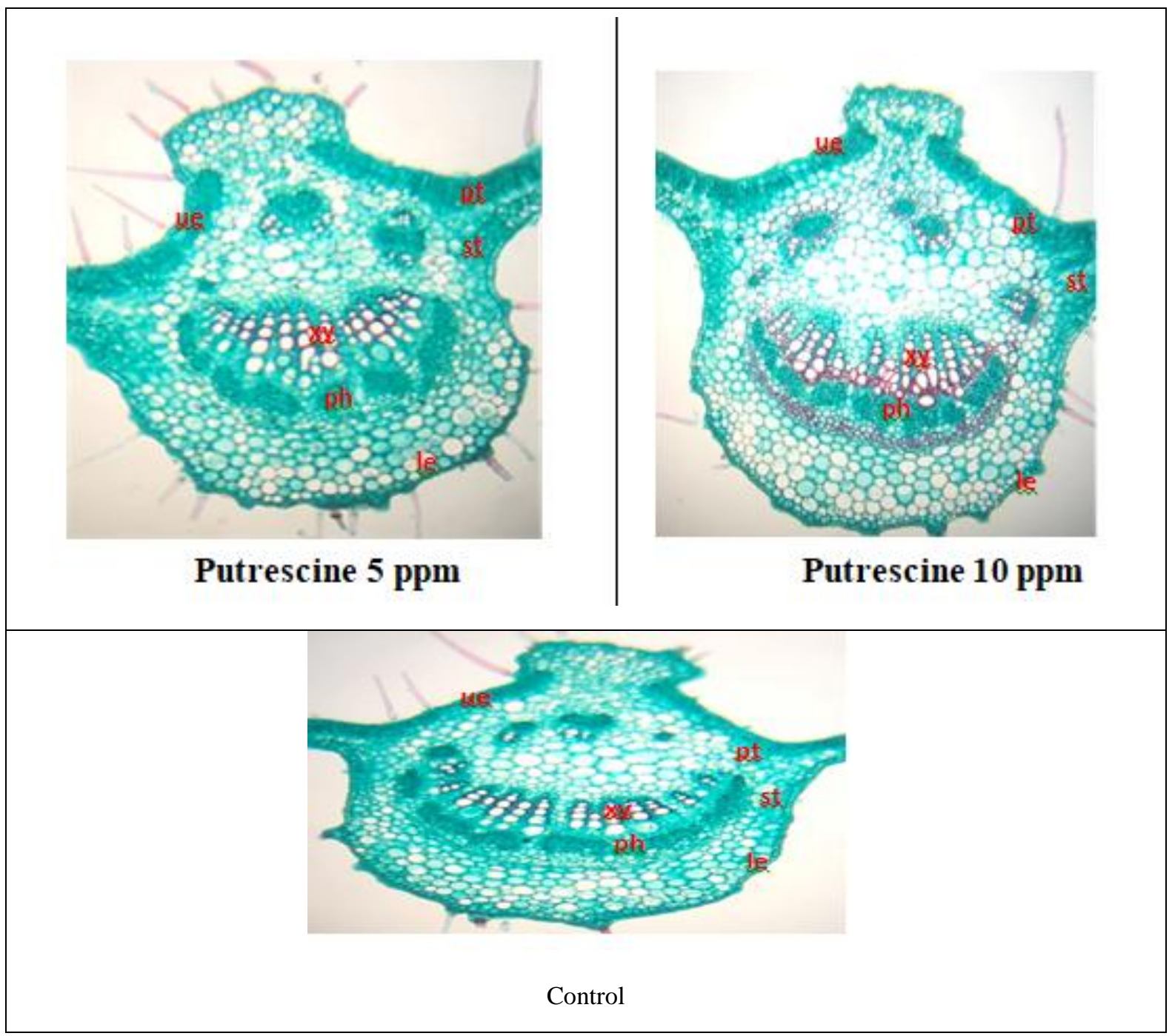

Fig. (3): Transverse sections $(X=24)$ through $2^{\text {nd }}$ apical leaf of cucumber plants at 30 days after transplanting as affected by the different applied treatments.

$\mathrm{ue}=$ Upper epidermis $\mathrm{pt}=$ Palisade tissue $\quad \mathrm{st}=$ Spongy tissue

le $=$ Lower epidermis $\quad \mathrm{ph}=$ Phloem tissue $\quad \mathrm{xy}=$ Xylem tissue 


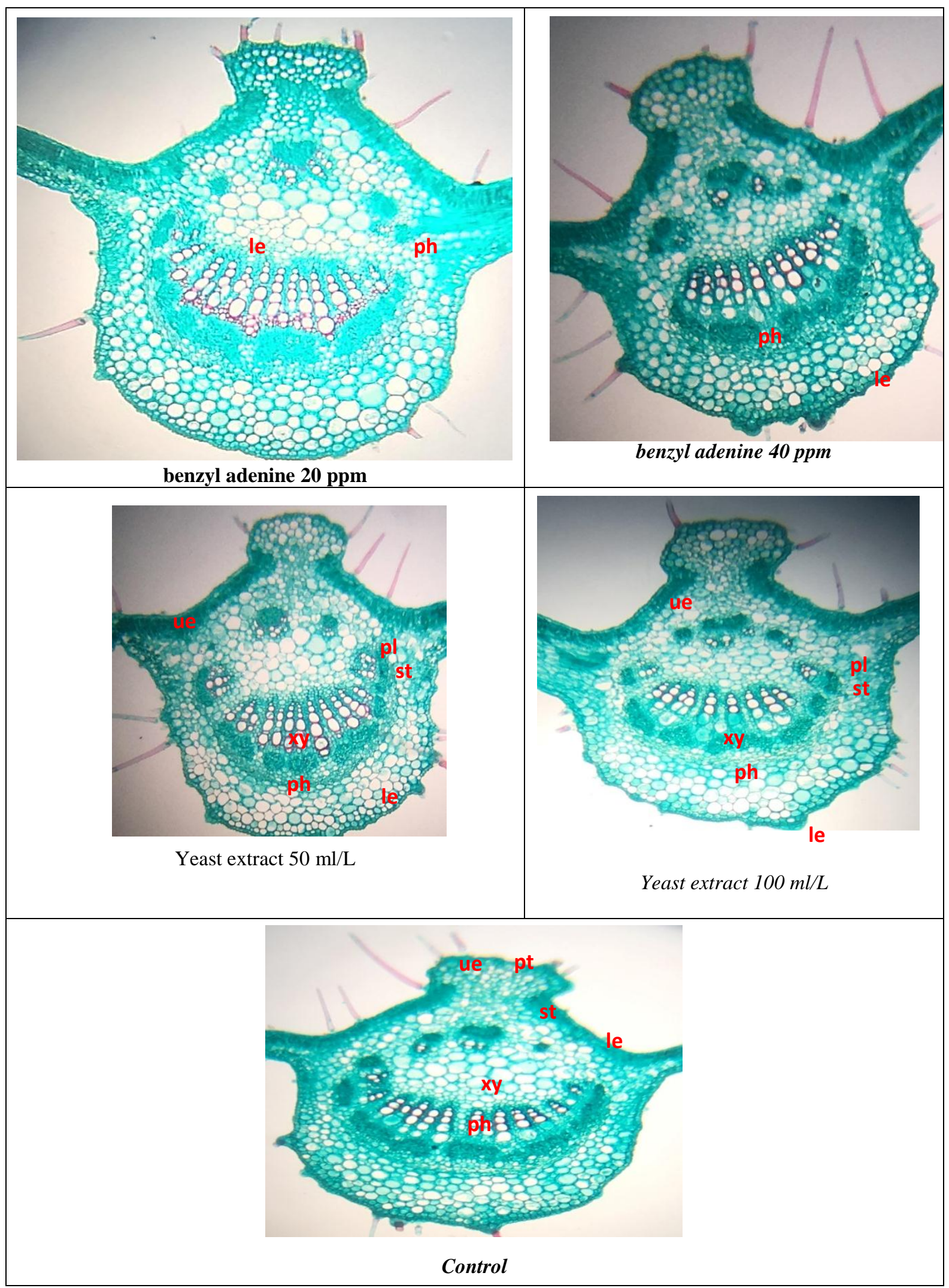

Fig. (4): Transverse sections $(X=24)$ through $2^{\text {nd }}$ apical leaf of soyabean plants at 60 days after transplanting as affected by the different applied treatments. ue $=$ Upper epidermis $\mathrm{pt}=$ Palisade tissue le $=$ Lower epidermis $\quad \mathrm{ph}=$ Phloem tissue

$\mathrm{st}=$ Spongy tissue
$\mathrm{xy}=$ Xylem tissue 


\section{V-Flowering, Yield and yield components:-}

Data in Table (5) showed the effect of Putrscine at $5,10 \mathrm{mg} / \mathrm{L}$, Benzyl adenine at 20 and $40 \mathrm{mg} / \mathrm{L}$ and yeast extract at $50 \& 100 \mathrm{ml} / \mathrm{L}$ on flower number, flower setting percentage, flower abscissions percentage, plant height $\mathrm{cm} /$ plant; pod number/plant (upper\& lower);pod weight/plant (upper\& lower); seed number/ pod (upper \&lower); weight of 100 seed (upper\& lower) and seed weight g/plant at harvest time during 2016 and 2017 seasons. Here, different applied treatments increased these traits (flowering and yield characteristics) during both seasons. In this respect, yeast extract at $100 \mathrm{ml} / \mathrm{L}$ gave the highest value with pod number (upper and lower; pod weight g/plant (upper and lower seeds number/pod (upper and lower, seeds weight g/pod compared with control plants during 2016 and 2017 seasons. Other applied treatments gave significant increase in these traits but did not reach the value of yeast extract treatment during both seasons. The enhancing effects of yeast extract application might be due to their contents of cytokinins enhance the accumulation of soluble metabolites. Yeast treatments were suggested to play a beneficial role in cell division and cell enlargement. Yeast as a natural stimulator is also characterized by richness in protein, carbohydrates, nucleic acid, lipids and different minerals and $\mathrm{Li}$ in addition to thiamin, riboflavin, pyridoxine, hormones and other growth regulating substances, biotin, $\mathrm{B}_{12}$ and folic acid (Nagodawithana,1991). In the same time increasing of growth aspects in Tables (1) especially with leaf area, leaf number, dry weight and accompanied with increasing of photosynthetic pigments as in Table (2) these are good indicators for improving soya bean yield and quality especially fully seeds in the upper part (fully seeds number and weight) as in Table (5).

Fig 5. Effect of different applied treatments on endogenous phytohormones content in shoots of Soyabean plants at 60 days after sowing during 2017 the second growing season.

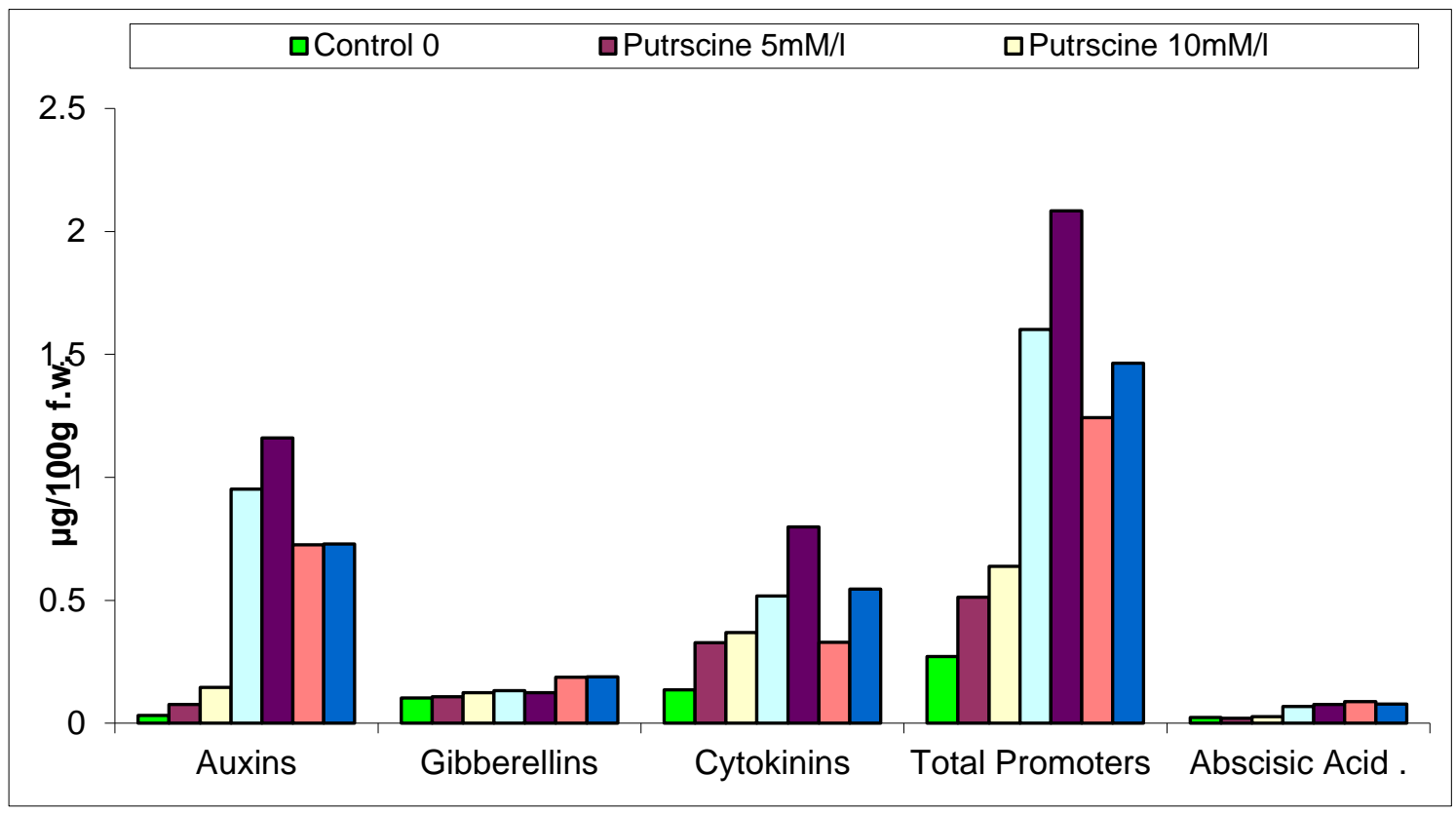


Table 1. Effect of different applied treatments on some morphological characteristics of soybean (Glycinemax L.) plants at 60 and 80 days after sowingduring 2016 and 2017seasons.

\begin{tabular}{|c|c|c|c|c|c|c|c|c|c|c|c|c|c|c|c|c|}
\hline \multirow[t]{3}{*}{ Characteristics } & \multicolumn{4}{|c|}{ Plant height $\mathrm{cm} . /$ plant } & \multicolumn{4}{|c|}{ Stem diameter cm./plant } & \multicolumn{4}{|c|}{ Number of leaves /plant } & \multicolumn{4}{|c|}{ Number of branches /plant } \\
\hline & \multicolumn{2}{|c|}{ At 60 days } & \multicolumn{2}{|c|}{ At 80 days } & \multicolumn{2}{|c|}{ At 60 days } & \multicolumn{2}{|c|}{ At 80 days } & \multicolumn{2}{|c|}{ At 60 days } & \multicolumn{2}{|c|}{ At 80 days } & \multicolumn{2}{|c|}{ At 60 days } & \multicolumn{2}{|c|}{ At 80 days } \\
\hline & 2016 & 2017 & 2016 & 2017 & 2016 & 2017 & 2016 & 2017 & 2016 & 2017 & 2016 & 2017 & 2016 & 2017 & 2016 & 2017 \\
\hline \multicolumn{17}{|l|}{ Treatments } \\
\hline Control & 73.33 & 63.00 & 80.83 & 75.33 & 0.42 & 0.47 & 0.68 & 0.57 & 16.17 & 26.33 & 50.17 & 41.00 & 4.83 & 4.83 & 7.33 & 7.67 \\
\hline Putrscine $5 \mathrm{mg} / \mathrm{L}$. & 85.33 & 58.67 & 86.67 & 86.00 & 0.82 & 0.73 & 0.72 & 0.73 & 21.83 & 33.67 & 87.50 & 59.67 & 7.00 & 7.00 & 10.00 & 11.33 \\
\hline Putrscine $10 \mathrm{mg} / \mathrm{L}$. & 80.67 & 65.00 & 101.00 & 88.00 & 0.62 & 0.53 & 0.88 & 0.77 & 29.50 & 36.00 & 88.33 & 86.33 & 6.67 & 6.67 & 9.83 & 7.33 \\
\hline Benzyl adenine $20 \mathrm{mg} / \mathrm{L}$ & 78.33 & 52.33 & 109.50 & 83.33 & 0.75 & 0.53 & 0.98 & 0.87 & 25.67 & 31.67 & 71.33 & 81.33 & 7.83 & 7.83 & 11.17 & 13.33 \\
\hline Benzyl adenine $40 \mathrm{mg} / \mathrm{L}$ & 89.83 & 59.00 & 101.00 & 95.67 & 0.63 & 0.50 & 1.00 & 0.67 & 28.00 & 34.66 & 64.67 & 76.67 & 9.67 & 8.67 & 12.33 & 12.67 \\
\hline yeast extract $50 \mathrm{ml} / \mathrm{L}$ & 82.00 & 55.67 & 86.50 & 92.00 & 0.72 & 0.73 & 0.92 & 0.97 & 20.00 & 31.00 & 65.83 & 78.67 & 7.83 & 7.83 & 8.17 & 7.00 \\
\hline yeast extract $100 \mathrm{ml} / \mathrm{L}$ & 81.83 & 61.67 & 101.00 & 99.33 & 0.53 & 0.60 & 0.92 & 0.93 & 19.50 & 29.67 & 64.17 & 71.00 & 6.50 & 6.50 & 10.33 & 9.67 \\
\hline LSD at $0.005 \%$ & 4.53 & 3.25 & 4.23 & 4.15 & 0.12 & 0.15 & 0.22 & 0.29 & 2.50 & 2.66 & 2.75 & 2.33 & 0.321 & 0.325 & 0.564 & 0.569 \\
\hline Characteristics & \multicolumn{5}{|c|}{ Total Leaf area $\mathrm{cm}^{2} /$ plant } & \multicolumn{6}{|c|}{ Shoots fresh weight $\mathrm{g} / \mathrm{plant}$} & \multicolumn{5}{|c|}{ Shoots dry weight g/plant } \\
\hline & \multicolumn{2}{|c|}{ At 60 days } & \multicolumn{3}{|c|}{ At 80 days } & \multicolumn{3}{|c|}{ At 60 days } & \multicolumn{3}{|c|}{ At 80 days } & \multicolumn{2}{|c|}{ At 60 days } & \multicolumn{3}{|c|}{ At 80 days } \\
\hline Treatments & 2016 & 2017 & 2016 & & 017 & 2016 & & 17 & 2016 & 20 & 17 & 2016 & 2017 & & 2016 & 2017 \\
\hline Control & 1625.90 & 2496.93 & 3910.90 & 297 & 73.26 & 78.11 & & 74 & 154.3 & 118 & .72 & 19.36 & 24.72 & & 4.39 & 42.59 \\
\hline Putrscine $5 \mathrm{ml} / \mathrm{L}$. & 2834.47 & 3148.57 & 4476.82 & 433 & 39.33 & 139.2 & & .98 & 202.29 & 185 & .95 & 32.75 & 33.74 & & 9.03 & 73.55 \\
\hline Putrscine $10 \mathrm{ml} / \mathrm{L}$. & 2687.22 & 2725.50 & 4018.22 & 317 & 79.55 & 137.53 & & .38 & 187.14 & 139 & .57 & 30.94 & 32.68 & & 6.25 & 73.12 \\
\hline Benzyl adenine $20 \mathrm{mg} / \mathrm{L}$ & 2007.97 & 2798.83 & 5762.02 & 437 & 72.71 & 117.14 & & .38 & 226.91 & 202 & .47 & 23.83 & 31.36 & & 9.08 & 64.83 \\
\hline Benzyl adenine $40 \mathrm{mg} / \mathrm{L}$ & 2533.77 & 3065.33 & 5069.92 & 338 & 34.57 & 120.28 & & .34 & 228.1 & 223 & .61 & 26.12 & 36.54 & & 0.96 & 67.3 \\
\hline yeast extract $50 \mathrm{ml} / \mathrm{L}$ & 2840.13 & 4210.33 & 5963.82 & 564 & 99.78 & 152.74 & & .29 & 249.14 & 242 & .83 & 38.2 & 47.7 & & 6.79 & 99.34 \\
\hline yeast extract $100 \mathrm{ml} / \mathrm{L}$ & 2938.91 & 3591.67 & 5669.26 & 544 & 77.67 & 75.42 & & .62 & 221.13 & 218 & .04 & 36.31 & 42.63 & & 3.06 & 97.78 \\
\hline LSD at $0.005 \%$ & 122.13 & 110.25 & 105.22 & & 3.17 & 1.35 & & 65 & 1.36 & 1. & 45 & 0.511 & 0.455 & & .645 & 0.487 \\
\hline
\end{tabular}


Table 2. Effect of different applied treatments on photosynthetic pigments content of soybean (Glycinemax L.) plants at 60 and 80 days after sowingduring 2016 and 2017seasons.

\begin{tabular}{|c|c|c|c|c|c|c|c|c|c|c|c|c|}
\hline \multirow{3}{*}{$\begin{array}{l}\text { Characteristics } \\
\text { Treatments }\end{array}$} & \multicolumn{4}{|c|}{ Chlorophyll a } & \multicolumn{4}{|c|}{ Chlorophyll b } & \multicolumn{4}{|c|}{ Chlorophyll a + b } \\
\hline & \multicolumn{2}{|c|}{ At 60 days } & \multicolumn{2}{|c|}{ At 80 days } & \multicolumn{2}{|c|}{ At 60 days } & \multicolumn{2}{|c|}{ At 80 days } & \multicolumn{2}{|c|}{ At 60 days } & \multicolumn{2}{|c|}{ At 80 days } \\
\hline & 2016 & 2017 & 2016 & 2017 & 2016 & 2017 & 2016 & 2017 & 2016 & 2017 & 2016 & 2017 \\
\hline Control & 0.988 & 1.140 & 0.886 & 1.109 & 1.054 & 0.686 & 0.705 & 0.631 & 2.042 & 1.826 & 1.591 & 1.74 \\
\hline Putrscine $5 \mathrm{ml} / \mathrm{L}$. & 1.389 & 1.777 & 0.907 & 1.365 & 1.193 & 0.958 & 0.977 & 0.703 & 2.582 & 2.735 & 1.884 & 2.068 \\
\hline Putrscine 10 ml/L. & 1.427 & 1.496 & 0.952 & 1.466 & 1.269 & 1.029 & 0.848 & 0.739 & 2.696 & 2.525 & 1.800 & 2.205 \\
\hline Benzyl adenine $20 \mathrm{mg} / \mathrm{L}$ & 1.582 & 1.778 & 0.822 & 1.306 & 1.136 & 1.100 & 0.822 & 0.875 & 2.718 & 2.878 & 1.644 & 2.181 \\
\hline Benzyl adenine $40 \mathrm{mg} / \mathrm{L}$ & 1.341 & 1.889 & 0.750 & 1.500 & 1.243 & 0.880 & 0.992 & 0.837 & 2.584 & 2.769 & 1.742 & 2.337 \\
\hline yeast extract $50 \mathrm{ml} / \mathrm{L}$ & 1.255 & 1.844 & 0.793 & 1.427 & 1.203 & 1.119 & 0.771 & 0.965 & 2.458 & 2.963 & 1.564 & 2.392 \\
\hline yeast extract $100 \mathrm{ml} / \mathrm{L}$ & 1.104 & 1.819 & 0.815 & 1.540 & 1.205 & 0.969 & 0.730 & 0.938 & 2.309 & 2.788 & 1.545 & 2.478 \\
\hline LSD at $0.005 \%$ & 0.025 & 0.035 & 0.0125 & 0.0356 & 0.028 & 0.035 & 0.0250 & 0.0125 & 0.112 & 0.222 & 0.156 & 0.135 \\
\hline Charactractics & \multicolumn{4}{|c|}{ Carotenoids } & \multicolumn{8}{|c|}{ Chl a + b / cart. } \\
\hline & \multicolumn{2}{|c|}{ At 60 days } & \multicolumn{2}{|c|}{ At 80 days } & \multicolumn{4}{|c|}{ At 60 days } & \multicolumn{4}{|c|}{ At 80 days } \\
\hline Treatments & 2016 & 2017 & 2016 & 2017 & & 2016 & & 2017 & & 2016 & & 2017 \\
\hline Control & 1.089 & 0.904 & 1.031 & 1.080 & & 1.875 & & 2.020 & & 1.543 & & 1.611 \\
\hline Putrscine $5 \mathrm{ml} / \mathrm{L}$. & 1.264 & 1.033 & 1.228 & 1.140 & & 2.043 & & 2.648 & & 1.534 & & 1.814 \\
\hline Putrscine $10 \mathrm{ml} / \mathrm{L}$. & 1.479 & 1.221 & 1.154 & 1.206 & & 1.823 & & 2.068 & & 1.560 & & 1.828 \\
\hline Benzyladenine $20 \mathrm{mg} / \mathrm{L}$ & 1.727 & 1.040 & 1.009 & 1.220 & & 1.574 & & 2.767 & & 1.629 & & 1.788 \\
\hline Benzyladenine $40 \mathrm{mg} / \mathrm{L}$ & 1.335 & 1.168 & 0.891 & 1.245 & & 1.936 & & 2.371 & & 1.955 & & 1.877 \\
\hline yeast extract $50 \mathrm{ml} / \mathrm{L}$ & 1.627 & 1.137 & 0.919 & 1.294 & & 1.511 & & 2.606 & & 1.702 & & 1.849 \\
\hline yeast extract $100 \mathrm{ml} / \mathrm{L}$ & 1.543 & 1.099 & 0.993 & 1.226 & & 1.496 & & 2.537 & & 1.556 & & 2.021 \\
\hline LSD at $0.005 \%$ & 0.168 & 0.212 & 0.139 & 0.148 & & 0.225 & & 0.238 & & .178 & & 0.239 \\
\hline
\end{tabular}


Table 4. Effect of different applied treatments on the mean counts and measurements of certain histological features of Soya bean ( Glycine max L) main stem and leaf at 60 days after sowing.

\begin{tabular}{|c|c|c|c|c|c|c|c|}
\hline Characters ( micron) & $\begin{array}{c}\text { Putrescine } \\
5 \mathrm{mg} / \mathrm{L}\end{array}$ & $\begin{array}{c}\text { Putrescine } \\
10 \mathrm{mg} / \mathrm{L}\end{array}$ & $\begin{array}{c}\text { BA } \\
20 \mathrm{mg} / \mathrm{L}\end{array}$ & $\begin{array}{c}\text { BA } \\
40 \mathrm{mg} / \mathrm{L} \\
\end{array}$ & $\begin{array}{c}\text { Yeast } \\
50 \mathrm{ml} \backslash \mathrm{I}\end{array}$ & $\begin{array}{c}\text { Yeast } \\
100 \mathrm{ml} \backslash \mathrm{I}\end{array}$ & Control \\
\hline \multicolumn{8}{|c|}{ Stem measurements } \\
\hline Stem diameter. & 4845.80 & 5382.00 & 5182.20 & 4048.20 & 4676.40 & 4541.40 & 3067.20 \\
\hline No. of vascular bundle. & 15.00 & 18.00 & 16.00 & 16.00 & 16.00 & 16.00 & 16.00 \\
\hline Thickness of fibers layers in large vascular bundle. & 73.80 & 81.00 & 117.00 & 99.00 & 76.50 & 81.00 & 45.00 \\
\hline Thickness of phloem in large vascular bundle. & 180.00 & 135.00 & 146.00 & 153.00 & 180.00 & 171.00 & 126.00 \\
\hline Thickness of cambium layers in large vascular bundle. & 80.00 & 90.00 & 85.00 & 79.50 & 81.00 & 81.00 & 45.00 \\
\hline Thickness of xylem in large vascular bundle. & 549.00 & 616.50 & 495.00 & 315.00 & 477.00 & 360.00 & 270.00 \\
\hline No. of xylem rows in large vascular bundle. & 8.00 & 9.00 & 8.00 & 8.00 & 7.00 & 6.00 & 4.00 \\
\hline No. of vessels in the xylem row in large vascular bundle. & 7.00 & 9.00 & 7.50 & 6.00 & 5.00 & 6.00 & 5.00 \\
\hline Thickness of widest xylem vessel in large vascular bundle. & 90.00 & 108.00 & 99.00 & 67.50 & 85.50 & 76.50 & 40.50 \\
\hline \multicolumn{8}{|c|}{ Leaf measurements } \\
\hline Thickness of midrib of leaf. & 1291.50 & 1458.00 & 1350.00 & 1359.00 & 1530.00 & 1440.00 & 1449.00 \\
\hline Thickness of blade. & 156.60 & 241.20 & 203.40 & 183.60 & 195.30 & 153.90 & 81.00 \\
\hline No. of vascular bundles in midrib. & 3.00 & 5.00 & 5.00 & 3.00 & 4.00 & 5.00 & 4.00 \\
\hline Length of large midrib vascular bundle. & 398.70 & 432.00 & 414.00 & 368.5 & 441.00 & 351.00 & 346.50 \\
\hline Width of large midrib vascular bundle. & 720.00 & 855.00 & 720.00 & 720.00 & 594.00 & 720.00 & 900.00 \\
\hline Thickness of fibers in vascular bundle. & 96.20 & 91.00 & 85.00 & 85.00 & 81.00 & 83.00 & 76.50 \\
\hline Thickness of phloem in vascular bundle. & 99.00 & 99.00 & 93.00 & 94.00 & 92.00 & 94.00 & 90.00 \\
\hline Thickness of xylem in vascular bundle. & 283.50 & 252.00 & 279.00 & 274.50 & 270.00 & 198.00 & 180.00 \\
\hline No. of xylem rows in vascular bundle. & 15.00 & 15.00 & 12.00 & 13.00 & 10.00 & 12.00 & 10.00 \\
\hline No. of vessels in the xylem row. & 8.50 & 6.00 & 7.00 & 6.00 & 5.00 & 5.00 & 4.50 \\
\hline Thickness of widest xylem vessel in vascular bundle & 72.00 & 81.00 & 67.50 & $\mathbf{5 7 . 0 0}$ & 72.00 & 49.50 & 45.00 \\
\hline
\end{tabular}


Table 5. Effect of different applied treatments on flowering measurements, yield and yield components of soybean (Glycine max ,L) plants at harvest time during 2016 and 2017seasons.

\begin{tabular}{|c|c|c|c|c|c|c|c|c|c|c|c|c|c|c|c|}
\hline \multirow{3}{*}{$\begin{array}{l}\text { Characteristics } \\
\text { Treatments }\end{array}$} & \multirow{2}{*}{\multicolumn{3}{|c|}{ No. of flowers/plant }} & \multirow{2}{*}{\multicolumn{2}{|c|}{ Flower setting \% }} & \multirow{2}{*}{\multicolumn{2}{|c|}{$\begin{array}{c}\text { Flower } \\
\text { Abscissions } \%\end{array}$}} & \multirow{2}{*}{\multicolumn{2}{|c|}{$\begin{array}{c}\text { Plant height } \\
\mathrm{cm} . / \text { plant }\end{array}$}} & \multicolumn{4}{|c|}{ Pods number/plant } & \multirow{2}{*}{\multicolumn{2}{|c|}{$\begin{array}{c}\text { Pods } \\
\text { weight/plant } \\
\text { Upper part }\end{array}$}} \\
\hline & & & & & & & & & & \multicolumn{2}{|c|}{ Upper part } & \multicolumn{2}{|c|}{ Lower part } & & \\
\hline & \multicolumn{2}{|c|}{2016} & 2017 & 2016 & 2017 & 2016 & 2017 & 2016 & 2017 & 2016 & 2017 & 2016 & 2017 & 2016 & 2017 \\
\hline Control & \multicolumn{2}{|c|}{161.00} & 189.00 & 62.79 & 60.85 & 37.21 & 39.15 & 82.83 & 84.33 & 11.67 & 14.33 & 108.17 & 107.33 & 6.87 & 9.61 \\
\hline Putrscine $5 \mathrm{ml} / \mathrm{L}$. & \multicolumn{2}{|c|}{156.33} & 252.40 & 74.24 & 74.64 & 25.76 & 25.36 & 88.16 & 87.00 & 22.83 & 25.33 & 115.50 & 151.00 & 13.69 & 15.45 \\
\hline Putrscine $10 \mathrm{ml} / \mathrm{L}$. & \multicolumn{2}{|c|}{169.66} & 218.00 & 80.73 & 74.13 & 19.27 & 25.87 & 86.83 & 89.67 & 24.33 & 26.00 & 166.67 & 165.00 & 14.81 & 16.88 \\
\hline $\begin{array}{l}\text { Benzyl adenine } \\
20 \mathrm{mg} / \mathrm{L}\end{array}$ & \multicolumn{2}{|c|}{207.00} & 290.00 & 81.93 & 79.45 & 15.07 & 20.55 & 84.33 & 92.00 & 23.50 & 32.00 & 165.17 & 231.67 & 13.79 & 17.46 \\
\hline $\begin{array}{l}\text { Benzyl adenine } \\
40 \mathrm{mg} / \mathrm{L}\end{array}$ & \multicolumn{2}{|c|}{187.66} & 248.60 & 80.28 & 82.95 & 19.72 & 17.05 & 88.17 & 88.00 & 27.83 & 33.33 & 168.50 & 148.00 & 16.44 & 18.06 \\
\hline yeast extract $50 \mathrm{ml} / \mathrm{L}$ & \multicolumn{2}{|c|}{289.66} & 297.40 & 82.49 & 83.23 & 19.51 & 21.77 & 92.67 & 88.00 & 25.50 & 33.33 & 140.83 & 183.33 & 15.20 & 17.58 \\
\hline yeast extract $100 \mathrm{ml} / \mathrm{L}$ & 298. & & 298.60 & 82.64 & 83.32 & 17.36 & 17.68 & 88.33 & 89.00 & 28.00 & 35.33 & 181.00 & 275.33 & 17.22 & 19.50 \\
\hline LSD at $0.005 \%$ & 10.1 & & 15.11 & 1.31 & 1.25 & 2.25 & 2.02 & 1.322 & 1.423 & 0.259 & 0.349 & 0.625 & 0.679 & 0.125 & 0.214 \\
\hline Charactractics & $\begin{array}{r}\mathbf{P} \\
\text { weigh }\end{array}$ & $\begin{array}{l}\text { plant } \\
\text { plat }\end{array}$ & & Seed & lumber/p & od & & & Seeds we & ight g/ pc & & & $\begin{array}{l}0 \text { seeds } \\
\text { eight }\end{array}$ & $\begin{array}{r}S \\
\text { weig }\end{array}$ & $\begin{array}{l}\text { eeds } \\
\text { ht/plant }\end{array}$ \\
\hline & Lowe & part & UpI & r part & & ower p & & Uppe & part & Low & er part & & & & \\
\hline Treatments & 2016 & 2017 & 2016 & 2017 & 2016 & & 2017 & 2016 & 2017 & 2016 & 2017 & 2016 & 2017 & 2016 & 2017 \\
\hline Control & 48.52 & 46.86 & 1.37 & 2.03 & 2.67 & & 2.77 & 2.45 & 3.67 & 4.23 & 4.31 & 18.36 & 18.18 & 30.11 & 32.05 \\
\hline Putrscine $5 \mathrm{ml} / \mathrm{L}$. & 56.21 & 63.59 & 2.20 & 2.80 & 2.97 & & 3.03 & 4.71 & 6.02 & 5.76 & 5.67 & 20.87 & 21.85 & 43.96 & 51.98 \\
\hline Putrscine $10 \mathrm{ml} / \mathrm{L}$. & 84.11 & 84.18 & 2.77 & 2.87 & 3.10 & & 3.07 & 5.09 & 5.71 & 5.96 & 6.04 & 19.38 & 21.13 & 60.99 & 61.18 \\
\hline $\begin{array}{l}\text { Benzyl adenine } \\
20 \mathrm{mg} / \mathrm{L}\end{array}$ & 80.72 & 102.36 & 2.78 & 2.90 & 3.03 & & 3.03 & 5.49 & 6.14 & 5.84 & 6.09 & 19.98 & 21.35 & 59.96 & 86.99 \\
\hline $\begin{array}{l}\text { Benzyl adenine } \\
40 \mathrm{mg} / \mathrm{L}\end{array}$ & 90.08 & 67.00 & 2.52 & 2.90 & 3.02 & & 3.03 & 5.52 & 6.35 & 5.99 & 6.15 & 20.96 & 21.45 & 58.96 & 55.50 \\
\hline yeast extract $50 \mathrm{ml} / \mathrm{L}$ & 63.26 & 99.33 & 2.60 & 2.87 & 2.95 & & 3.07 & 5.75 & 6.71 & 5.73 & 5.92 & 20.24 & 21.77 & 60.05 & 88.15 \\
\hline yeast extract $100 \mathrm{ml} / \mathrm{L}$ & 91.05 & 132.17 & 3.73 & 3.90 & 4.07 & & 4.10 & 5.69 & 6.44 & 6.92 & 6.21 & 21.67 & 22.46 & 86.99 & 97.14 \\
\hline LSD at $0.005 \%$ & 0.369 & 0.397 & 0.110 & 0.121 & 0.095 & & 0.123 & 0.146 & 0.159 & 0.197 & 0.138 & 0.248 & 0.269 & 3.25 & 4.66 \\
\hline
\end{tabular}




\section{Conclusion}

For maximizing the final yield of soyabean plants with good quality it could be achived with applying each of putrescine, at 5 and $10 \mathrm{mg} / \mathrm{L}$, Benzyl adenine at 20 and $40 \mathrm{mg} / \mathrm{L}$ and yeast extract at 50 and 100 $\mathrm{ml} /$ Lthree times during soya bean growth and development.

\section{References}

Abd-El-Hafez, A.E. and Shehata, S.F. 2001 .Field evaluation of yeasts as a bio-fertilizer for some vegetable crops. Arab Universities J. Agric. Sci., 9(1): 169-182.

Abdel-Rahim, E. A.; Shallan, M. A. and El-Scheik, A. M. 1988 : Biochemical studies on production of new thermophilic yeast alkaline proteases applied for the purposes of laundry detergents industry. J. Agric. Sci. Mansoura Univ., 21 (5): 1971-1985.

Abou Zaid, M. 1984 .Biochemical studies on fodder yeast. Ph. D. Thesis Fac. Agric. Cairo Univ. Egypt.

Alcázar R, Altabella T, Marco F, Bortolotti C, Reymond M, Koncz C, Carrasco P,Tiburcio AF. Polyamines: (2010).Molecules with regulatory functions in plant abiotic stress tolerance. Planta;231:1237-1249.

Ahmed, P.; Kumar, A.; Gupta, A.; Sharma, S.; Hu, X.; ulRehman Hakeem, K. and Azooz, M.M. 2012 . Polyamines: Role in plants under a biotic stress. Crop Production for Agricultural Improvement, Chapter (19): 491-512.Springer Science Business Media B.V.

Amelior plants, 23: 95-107.

Bais, H.P. and Ravishankar, G.A. 2002 .Role of polyamines in the ontogeny of plants and their biotechnological applications. Plant Cell Tiss Organ Cult 69: 1-34.

Barnett, J.A.; Payne, R.W. and Yarrow, D. 1990 . Yeasts Characteristics and Identification. Cambridge Univ. Press Publi. By the Press Syndicate of the Univ. of Cambridge Camb.,pp: 999.

Davies, P.J. (1995). Plant Hormones: Physiology, Biochemistry and Molecular Biology. Kluwer Academic Publishers, Dordrecht, The Netherlands.,pp: 833.

Demir, D., Günes, A., Inal, A. and Alpaslan, M. 2004. Effects of humic acids on the yield and mineral nutrition of cucumber (cucumis sativus 1.) grown with different salinity levels.ishsactahorticulturae 492.

Derieux, M., R. K.and Montalanty, Y. 1973 .Etude de la surface foliaiveet de lactivitephotosynthetquecheskulkes hybrids de mais. Ann. Amelior Plants, 23:95-107.

Drolet, G.; Dumbroff, E. B.; Legge, R. L. and Thompson, J. E. 1986. Radical scavenging properties of polyamines.Phytochemistry. 25: 367 $-371$.

Duszka, K.; Clark, B.F.C.; Massino , F. and Barciszewski, J. 2009 .Biological activities of kinetin. In: Ramawat KG (eds) Herbal Drugs: Ethnomedicine to Modern Medicine. Verlag Berlin Heidelberg, Berlin, pp: 369- 380.

EL-Desuki, M. and EL-Gereadly, N. H.M. 2006 . Response of pea plants to foliar application of yeast extract. J. Agric. Sci. Mansoura Univ., 31(10): 6667-6674.

et de lactivitephotosynthetique chez kulkues hybrids de mais", Ann.

Fathy, E.S.L. and Farid, S. 1996 .The possibility of using vitamin B and yeast to delay senescence and improve growth and yield of common bean (Phaseolus vulgaris L.). J. Agric. Sci. Mansoura Univ., 21(4): 1415-1423.

Johanson, D.V. 1940 : Plant microtechnique. New York, London, McGraw-Hill Book Co. Inc. PP. 27-154.

Khedr, Z.M.A. and Farid, S.(2000). Response of naturally virus infected tomato plant to yeast extract and phosphoric acid application. Annals of Agric. Sci. Moshtohor, 38(2): 927-939.

Koshioka,M., Harada, J.; Noma, M.; Sassa, T.; Ogiama, K.; Taylor, J.S.; Rood, S.B.; Legge, R.L. and Pharis, R.P. 1983 : Reversed phase C18 high performance liquid Chromatography of acidicand conjugated gibberellins. J. Chromatgr., 256: 101-115.

Kuznetsov, V.V. and Shevyakova, N.I. 2007 . Polyamines and stress tolerance of plants. Plant Stress, 1(1): 50-71.

Lazzarotto, J.J. andHirakuri, M.H. (2011).Evolução e perspectivas de desempenhoeconômicoassociadas com a produção de sojanoscontextosmundialbrasileiro. Londrina: EmbrapaSoja, Documentos. 319: 1-46.

Liu, J.H.; Honda, C and Moriguchi, T. 2006a .Involvement of polyamine in floral and fruit development. JARQ 40: 51-58.

Liu, J.H.; Kitashiba, H.; Wang, J.; Ban, Y.e and Moriguchi, T. 2007 .Polyamines and their ability to provide environmental stress tolerance to plants. Plant Biotechnology, 24: 117-126.

Mahmoud, Asmaa R. (2004). Response of potato to different level of organic nitrogen application and yeast spraying solution. Egypt. J. Appl. Sci., 19(11): 382-393.

Mohamed, F.I.; Helal, F.A.and EL-Shabraway, R.A. 1999 . A comparative study on the effect of bread yeast and foliage nutrients application on productivity and quality of two pea cultivars. Egypt. J. Appl. Sci., 14(10): 284-299.

Nagodawithana, W. T. 1991 . Yeast technology. Universal foods cooperation Milwauke, Wisconsin.Published by Van Nostrand, New York. 
Nassar, Rania, M.A.; Ahmed, Y.M. and Nassar, Dalia, M. A. 2011 .Effect of foliar spray with active yeast extract on morphological, anatomical and yield characteristics of Kidney bean (Phaseolus vulgaris l.). Aust. J. Basic. Appl. Sci., 5(5): 1071-1079.

Nicander, B.; Stahi, U.; Bjorkman, P.O.andTillberg, E. 1993 :Immunoaffinitycopurification of cytokinins and analysis by highperformance liquidchromatography with ultraviolet spectrum-detection. Planta, 189: 312320 .

Nofal, O.A.; Hellal, F.A.; El Sayed, S.A.A. and Bakry, A.B. 2016 . Response of Peanut and Maize crops to foliar application of Algae extracts Under sandy soil condition. Res.J. Pharmaceutical, Biol. Chem. Sci., 7(5): 151-157.

Nonokawa, K.; Nakajima, T.; Nakamura, T. and Kokubun, M. 2012 .Effect of Synthetic Cytokinin Application on Pod Setting of Individual Florets within Raceme in Soybean. Plant Prod. Sci. 15: 79-81.

Peterson, C.M.; Williams, J.C. and Kuang, A. $\mathbf{2 0 0 5}$. Increased pod set of determinate cultivars of soybean Glycine max with 6- benzylaminopurine. In: Yashima Y, Kaihatsu A, Nakajima T, Kokubum M. Effects of Source / Sink Ratio and Cytokinin Aplication on Pod Set in Soybean. Plant Prod. Sci.,8: 139-144.

Snedecor, G.W. and Cochran, W.G. 1980 : Statistical methods. 7th Ed. Iowa State Univ. Press Ames. Iowa, USA.
Schmidt, R.E. 2005 . Biostimulants function in turfgrass nutrition. phD emeritus virginia tech.

Wettstein, D. 1957 . Chlorophyll, letal and dirsumicro spische formmech sell derplastideu, Exptl. Cell. Res., 12-427.

Yashima, Y.; Kaihatsu, A.; Nakajima, T. andKokubum, M. 2005 . Effects of Source / Sink Ratio and Cytokinin Aplication on Pod Set in Soybean. Plant Prod. Sci. 8: 139-144.

Yeo, E.; HawkBin, K.; SangEun, H.; JoonTak, L.; JinChang, R.; MyungOk, B.; Yeo, E.T.; Kwon, H.B.; Han, S.E.; Lee, J.T.; Ryu, J.C. and Byun, M.O. 2000 . Genetic engineering of drought resistant potato plants by introduction of the trehalose-6-phosphate synthase (TPSI) gene from Saccharomyces cerevisiae. Molecules and Cells., 10(3): 263-268.

Zewail, R. M. Y. 2014 .Effect of seaweed extract and amino acids on growth, productivity and some biocostituents of common bean (Phaseolus vulgaris l) plants. J. Plant Production, Mansoura Univ.,5 (8): 1441 - 1453.

Zewail, R.M.Y.; Khedr, Z.M.A. and Mady, M.A. 2011 . Effect of potassium, some antioxidants, phosphoric acid and napthalen acetic acid (NAA) on growth and productivity of faba bean plants (faba vulgaris) .Annals of Agric. Sci., Moshtohor, 49(1): 53-64.

Zhang, X. and Schmidt, R.E. 2000.. Hormone containing products' impact on antioxidant status of tall fescue and creeping bentgrass subjected to drought. Crop Science, v.40, p.1344-1349. 